\title{
Analysis of Carbohydrate, Moisture Content and Specific Gravity of Bambusa tulda with Special Reference to its Harvesting Season
}

\author{
Bebija L. Singha ${ }^{1}$, Yamin Hassan ${ }^{2}$ \\ ${ }^{1}$ Research Scholar, Assam down town University, Guwahati-26 and Research Assistant, RFRI, Jorhat, Assam \\ ${ }^{2}$ Assistant Professor, Chemistry, AdtU, Guwahati-26
}

\begin{abstract}
Bambusa tulda is one the most important bamboo species of northeast India. It is commonly used by rural people in basketary, fencing, housing, furniture, mats, poles and post musical instruments, weaving material, scaffolding, paper and pulp etc. Mature bamboos are usually harvested during off season. However, there is little information available on the correlation between time of harvesting and the nutrient status of bamboo. This paper describes the optimum harvesting season of Bambusa tulda for sustainable management. The result revealed that the optimum harvesting period was from October to January.
\end{abstract}

Keywords: Bambusa tulda; carbohydrates, harvesting period, sustainable management

\section{Introduction}

Bamboo plays a major role in the economy of rural people and in industry especially in India. Due to its remarkable growth and versatile properties, bamboos are used as agricultural tools, handles, building material, scaffolding, pole and post, weaving material, furniture, fishing rods, tender shoot as food, for fencing, particle board, bamboo ply board, in pulp and paper industries etc. Bamboo can be machined, glued and finished just like wood without much difficulty.

Like most lignocellulosic wood, bamboo also has very low resistance to biological degrading agents like fungi, termite, insect borers etc and these agents attacked bamboo furniture more as compared to timber (Liese, 1980). The natural durability of bamboo depends on age, moisture content, specific gravity, climatic conditions, type of use, carbohydrate content, felling season, physical properties and species (Liese, 1985; Plank, 1950 and Kumar et al. 1994). Due to lack of enough toxicity like resins, waxes and tannins to impart natural durability and presence of large amount of carbohydrates makes bamboo more attractive to biological degrading agents (Mathew and Nair, 1988 and Gnanarahan et al. 1993).

Bambusa tulda is one of the most grown or planted species by the rural people of northeast India due to its clean and straight culm, medium height, strength and easy availability. In this part of India, mature bamboo culms are harvesting during November to February months when the area is easily accessible and before the emergence of new shoots. Knowing when and how to harvest bamboo has been one of the most important and traditional bamboo preservation methods in areas with smaller resources.

Harvesting of matured bamboo during winter season is an age old practice (traditional) followed quite often in the Asian countries to enhance its durability against fungus and borers. These borers includes Dinoderus minutes Fab., D. ocellaris Steph., and D. brevis which is popularly known as "ghoon" in India (Sulthoni, 1987). Studies indicate that the starch content in bamboo is an important factor influencing the susceptibility to borer (Plank, 1950; 1951); the damage caused by the borer has been found proportional to the starch content of the bamboo (Purushotham, et al. 1953; Beeson 1961; Liese, 1980; Tamolang et al. 1980; Sulthoni, 1981).

To understand when to harvest mature bamboo culms, it is necessary to calculate the composition of bamboo. Bamboo possesses large amounts of sugars and starch which are the principal nutrients for parasites, borers and fungi. When carbohydrates are reduced, the bamboo culm will be more naturally resistant to these biological degrading organisms. The present study is to estimate the concentration of carbohydrates present in the culm during different months to find suitable harvesting period for harvesting.

\section{Materials and Methods}

Sample culms of B. tulda were collected from Jorhat district of Assam, India. Three mature culms of 3-4 years old $B$. tulda (Jati bah - locally) was collected at monthly interval for one full year starting from January 2013 to December 2013. Each culm was divided into three different portions basal, middle and apical. Each portion was further cut into 5 segments of $100 \mathrm{~cm}$ long for uniform estimation of carbohydrates. Samples from each segment of each portion from the three different culms were collected in the form of saw dust for analysis of total soluble sugars (TSS) and starch in laboratory every month. The remaining segments were labeled according to the name of the month in which the culm was harvested and stacked above ground using a wooden frame under cover for observing powder post beetle attack. Before stacking weight (in $\mathrm{kg}$ ), moisture content (in $\%$ ), outer and inner diameter (in $\mathrm{mm}$ ) of each segment were recorded using an electronic balance (Make: Goldface), a moisture meter (Make: Lutron WD4G), a vernier caliper (Make: Mitutoyo) respectively. 


\section{International Journal of Science and Research (IJSR) \\ ISSN (Online): 2319-7064 \\ Index Copernicus Value (2015): 78.96 | Impact Factor (2015): 6.391}

TSS and starch content of the species for 12 months were estimated by Anthrone method (Sadasivam and Manickum, 1996; Dutta, 2005 and Bartkiene, 2012). This method is widely used for the determination of soluble sugars and starch in plant material. The attack by powder post beetle was recorded by counting the number of holes made by them. The TSS and starch contents in the samples were estimated statistically and analyzed using ANOVA.

\section{Results and Discussion}

Average monthly TSS content of the bamboo species in percentage is given in Table 1. The highest average TSS content was measured in the month of June $(2.03 \%)$ followed by May $(1.86 \%)$. The lowest average TSS content was measured in the month of October $(0.65 \%)$. This variation may be due to physical changes occurred in different season which is a natural phenomenon of the species.

Average monthly starch content of the bamboo species in percentage is given in Table 2. The highest average starch content was measured in the month of June $(1.87 \%)$ followed by May $(1.76 \%)$ and the lowest average starch content was measured in the month of October $(0.63 \%)$. There was considerable variation in starch content between different portions. Maximum starch content may be stored by the species for giving new shoots in rainy season.

Average monthly moisture content of the bamboo species in percentage is given in Table 3. The highest average moisture content was recorded during the month of July $(38.86 \%)$ and lowest was recorded in the month of November $(25.19 \%)$. This may be due to deceasing rate of photosynthetic and transpiration process during winter.

Average monthly specific gravity of the bamboo species is given in Table 4. The highest average specific gravity was recorded in the month of October (2.25) and lowest average specific gravity was recorded in the month of June (0.54). Specific gravity of a bamboo culm is inversely related to the parenchyma cells, the cells which manufacture and store food including starch (Liese, 1987; Abdul latif et al. 1996 and Jamaluddin et al. 1994). The lower starch content was very much associated with the higher specific gravity of the culm.

Average monthly powder post beetles attack on the species based on 12 consecutive monthly felling varies in different month (Table 5). The highest average attack (no. of holes made) was recorded in the month of May $(8.95 \%)$ and lowest average attack was recorded in the month of December (0.38). The degree of attack may be due to the difference in nutrient content of the species during different periods of harvesting.
Table 1: Average total soluble sugars (\%) content at different portion of $B$. tulda culm based on 12 consecutive monthly felling

\begin{tabular}{|l|c|c|c|c|}
\hline \multirow{2}{*}{ Name of the month } & \multicolumn{5}{|c|}{ Average total soluble sugars content (\%) } \\
\cline { 2 - 5 } & Basal & Middle & Top & Average \\
\hline January & 0.87 & 0.69 & 0.56 & 0.70 \\
\hline February & 1.29 & 1.11 & 0.75 & $\mathbf{1 . 0 5}$ \\
\hline March & 1.48 & 1.35 & 0.82 & $\mathbf{1 . 2 1}$ \\
\hline April & 1.53 & 2.02 & 1.27 & $\mathbf{1 . 6 1}$ \\
\hline May & 4.77 & 3.35 & 3.02 & $\mathbf{3 . 7 1}$ \\
\hline June & 5.30 & 4.68 & 2.18 & $\mathbf{4 . 0 5}$ \\
\hline July & 1.11 & 1.47 & 1.38 & $\mathbf{1 . 3 2}$ \\
\hline August & 1.38 & 1.11 & 1.68 & $\mathbf{1 . 3 9}$ \\
\hline September & 1.04 & 0.92 & 0.73 & $\mathbf{0 . 9 0}$ \\
\hline October & 0.82 & 0.69 & 0.43 & $\mathbf{0 . 6 5}$ \\
\hline November & 0.92 & 0.79 & 0.68 & $\mathbf{0 . 8 0}$ \\
\hline December & 0.81 & 0.74 & 0.61 & $\mathbf{0 . 7 2}$ \\
\hline P-value & $1.32 \mathrm{E}-07$ & \multicolumn{4}{|l}{} \\
\hline SED & 0.22 & \multicolumn{5}{|l|}{} \\
\hline CD & 0.39 &
\end{tabular}

Table 2: Average starch content (\%) at different portion of B. tulda culm based on 12 consecutive monthly felling

\begin{tabular}{|l|c|c|c|c|}
\hline \multirow{2}{*}{ Name of the month } & \multicolumn{5}{|c|}{ Average starch content (\%) } \\
\cline { 2 - 5 } & Basal & Middle & Top & Average \\
\hline January & 0.78 & 0.62 & 0.59 & 0.66 \\
\hline February & 1.16 & 1.00 & 0.47 & 0.88 \\
\hline March & 1.33 & 1.22 & 1.07 & 1.20 \\
\hline April & 2.12 & 1.82 & 1.15 & 1.69 \\
\hline May & 4.30 & 3.02 & 2.71 & 3.34 \\
\hline June & 4.77 & 4.21 & 1.96 & 3.65 \\
\hline July & 2.93 & 2.09 & 1.24 & 2.09 \\
\hline August & 1.24 & 1.00 & 1.86 & 1.37 \\
\hline September & 0.94 & 0.83 & 0.85 & 0.87 \\
\hline October & 0.73 & 0.63 & 0.54 & 0.63 \\
\hline November & 0.83 & 0.71 & 0.57 & 0.70 \\
\hline December & 0.73 & 0.66 & 0.77 & 0.72 \\
\hline P-value & $8.18 \mathrm{E}-08$ \\
\hline SED & 0.20 & \multicolumn{5}{|l}{} \\
\hline CD & 0.34 &
\end{tabular}

Table 3: Average moisture content (\%) at different portion of B. tulda culm based on 12 consecutive monthly felling

\begin{tabular}{|c|c|c|c|c|}
\hline \multirow{2}{*}{ Name of the month } & \multicolumn{5}{|c|}{ Average moisture content (\%) } \\
\cline { 2 - 5 } & Basal & Middle & Top & Average \\
\hline January & 32.47 & 31.47 & 28.90 & 30.94 \\
\hline February & 32.43 & 31.00 & 29.30 & 30.91 \\
\hline March & 31.70 & 30.23 & 24.90 & 28.94 \\
\hline April & 30.07 & 27.43 & 29.70 & 29.07 \\
\hline May & 28.73 & 28.67 & 30.07 & 29.16 \\
\hline June & 36.96 & 34.04 & 32.36 & 34.45 \\
\hline July & 44.67 & 38.67 & 33.23 & 38.86 \\
\hline August & 36.00 & 32.53 & 30.21 & 32.91 \\
\hline September & 31.73 & 28.60 & 23.33 & 27.89 \\
\hline October & 32.03 & 28.67 & 20.80 & 27.17 \\
\hline November & 29.03 & 24.63 & 21.90 & 25.19 \\
\hline December & 29.70 & 26.87 & 24.27 & 26.94 \\
\hline P-value & \multicolumn{5}{|c|}{0.88} \\
\hline SED & \multicolumn{5}{|c|}{1.52} \\
\hline CD & \multicolumn{5}{|c|}{} \\
\hline
\end{tabular}




\section{International Journal of Science and Research (IJSR) \\ ISSN (Online): 2319-7064 \\ Index Copernicus Value (2015): 78.96 | Impact Factor (2015): 6.391}

Table 4: Corresponding average thickness and weight, length and Specific Gravity of B. tulda culm based on 12 consecutive monthly felling

\begin{tabular}{|c|c|c|c|c|c|}
\hline $\begin{array}{c}\text { Name of the } \\
\text { month }\end{array}$ & \multicolumn{2}{|c|}{$\begin{array}{c}\text { Average Diameter } \\
\text { of culm }(\mathrm{mm})\end{array}$} & $\begin{array}{c}\text { Average } \\
\text { Weight } \\
(\mathrm{Kg})\end{array}$ & $\begin{array}{c}\text { Length of } \\
\text { each } \\
\text { section }\end{array}$ & $\begin{array}{c}\text { Specific } \\
\text { Gravity } \\
(\mathrm{w} / \mathrm{v})\end{array}$ \\
\hline & Outer & Inner & 1.15 & 100 & 1.53 \\
\hline January & 56.89 & 40.57 & 1.15 & 100 & 1.04 \\
\hline February & 55.61 & 40.63 & 1.04 & 100 & 1.03 \\
\hline March & 46.23 & 30.37 & 1.04 & 100 & 0.77 \\
\hline April & 39.74 & 24.54 & 1.27 & 100 & 0.76 \\
\hline May & 45.05 & 28.18 & 0.79 & 100 & 0.54 \\
\hline June & 49.67 & 36.33 & 0.85 & 100 & 0.03 \\
\hline July & 39.63 & 29.23 & 0.94 & 100 & 1.03 \\
\hline August & 46.29 & 32.93 & 0.89 & 100 & 0.93 \\
\hline September & 43.88 & 34.33 & 0.99 & 100 & 1.08 \\
\hline October & 45.11 & 33.28 & 2.11 & 100 & 2.25 \\
\hline November & 43.54 & 31.5 & 1.39 & 100 & 1.13 \\
\hline December & 43.2 & 32.84 & 0.85 & 100 & 1.19 \\
\hline
\end{tabular}

Table 5: Average powder post beetle attack (no. of holes made) at different portion of B. tulda culm based on 12 consecutive monthly felling

\begin{tabular}{|l|c|c|c|c|}
\hline \multirow{2}{*}{ MONTH } & \multicolumn{5}{|c|}{ Average no. of holes made powder post beetle } \\
\cline { 2 - 5 } & Basal & Middle & Top & Average \\
\hline January & 0.76 & 0.85 & 1.08 & 0.90 \\
\hline February & 1.31 & 1.22 & 1.43 & 1.32 \\
\hline March & 1.74 & 2.52 & 1.97 & 2.08 \\
\hline April & 2.85 & 1.89 & 2.42 & 2.39 \\
\hline May & 11.05 & 8.56 & 7.24 & 8.95 \\
\hline June & 4.32 & 6.13 & 3.41 & 4.62 \\
\hline July & 4.56 & 5.87 & 3.74 & 4.72 \\
\hline August & 7.41 & 5.95 & 4.58 & 5.98 \\
\hline September & 6.23 & 5.44 & 2.82 & 4.83 \\
\hline October & 3.11 & 1.27 & 3.95 & 2.78 \\
\hline November & 2.73 & 1.73 & 1.14 & 1.87 \\
\hline December & 0.23 & 0.64 & 0.28 & 0.38 \\
\hline P-value & $2.36 \mathrm{E}-08$ & \multicolumn{5}{l}{} \\
\hline SED & 0.44 & \multicolumn{5}{l}{} \\
\hline CD & 0.76 &
\end{tabular}

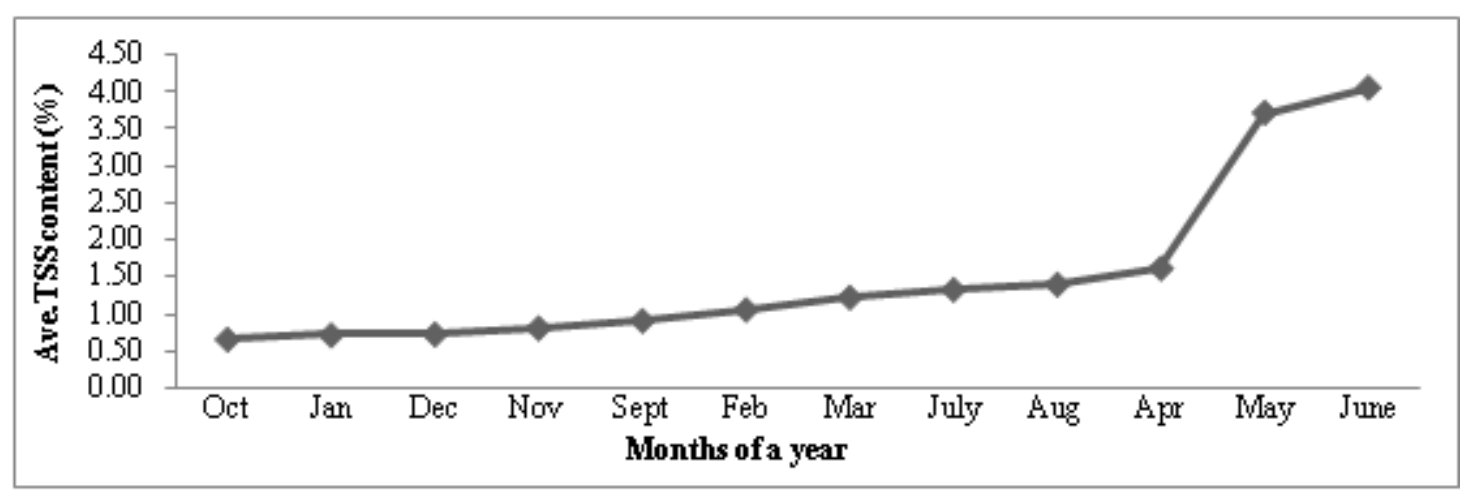

Figure 1: Graph showing lowest to highest TSS content in the $B$. tulda culm estimated during different months of a year

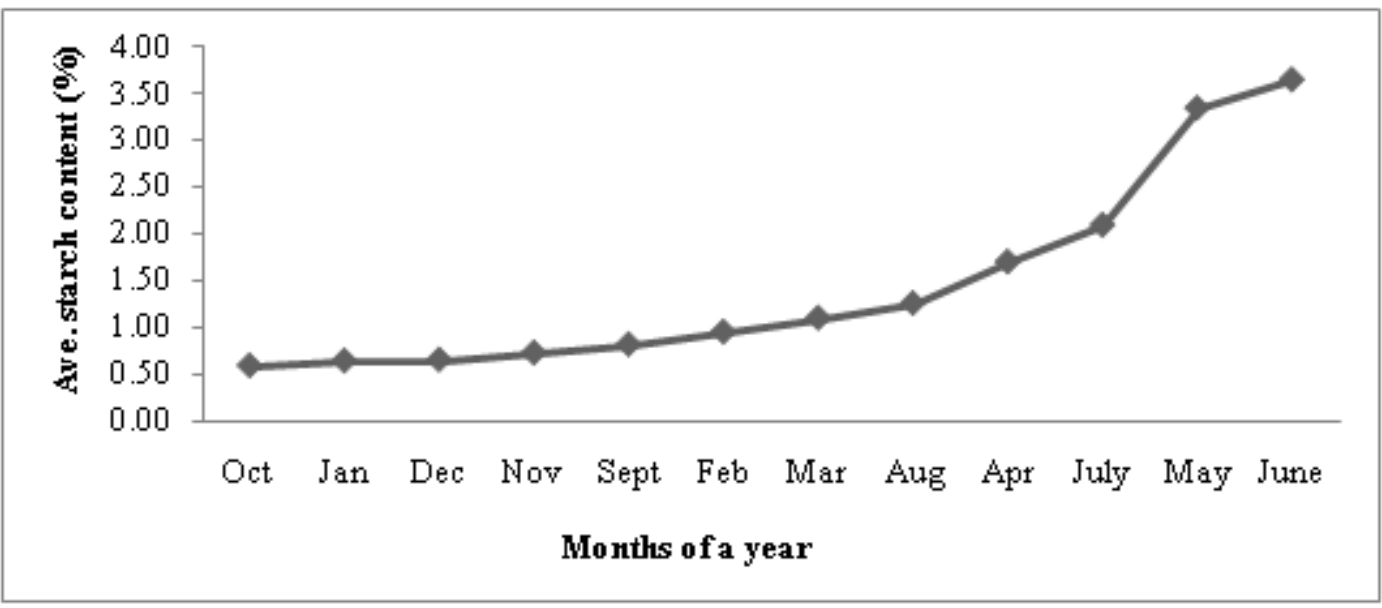

Figure 2: Graph showing lowest to highest starch content in the B. tulda culm estimated during different months of a year 
International Journal of Science and Research (IJSR)

ISSN (Online): 2319-7064

Index Copernicus Value (2015): 78.96 | Impact Factor (2015): 6.391

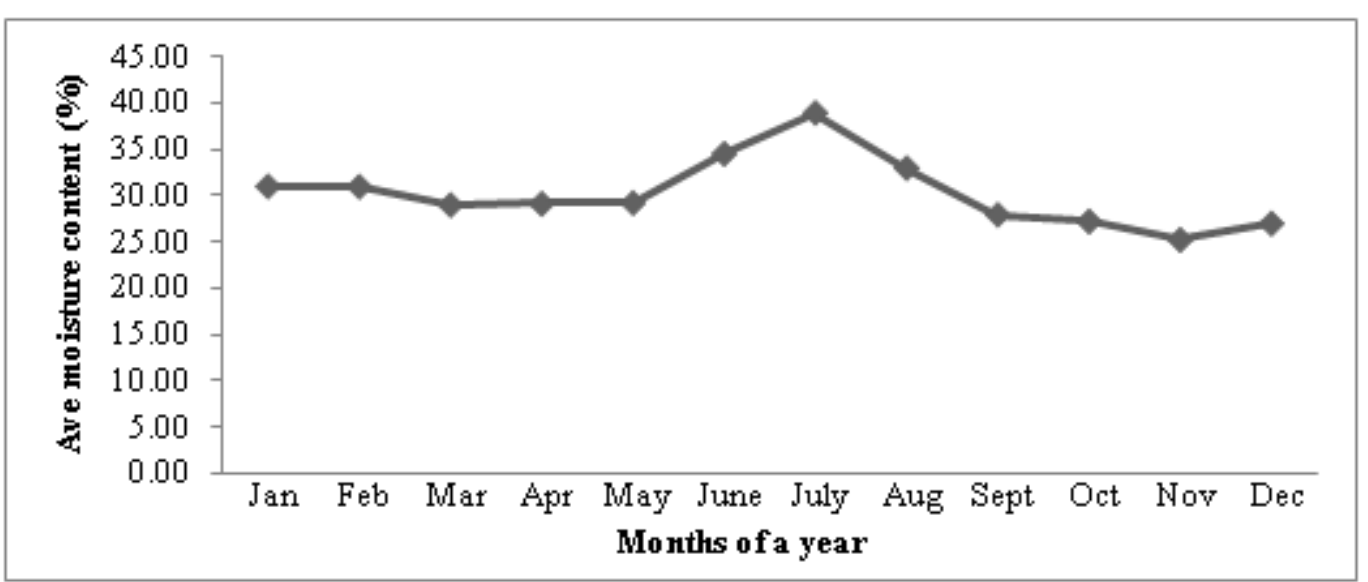

Figure 3: Graph showing lowest to highest moisture content in the B. tulda culm recorded during different months of a year

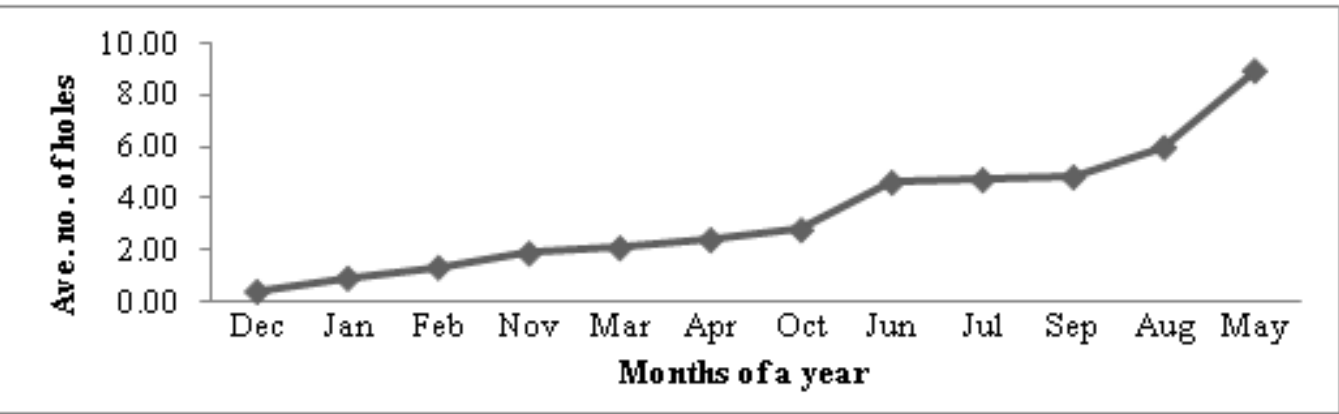

Figure 4: Graph showing lowest to highest no. of holes made by powder post beetle in the stack of $B$. tulda harvested in different month of a year

\section{Conclusions}

From the analysis of carbohydrates and moisture contents it was found that amount of sugar, starch and moisture contents decreases during winter season and the corresponding powder post beetle attack on the harvested bamboo culms were also found to be deceased during this period. It may be therefore one the main reason that traditional felling of bamboo is done during winter season. The pragmatic knowledge about bamboo preservation developed by indigenous communities of Assam, India through the centuries is cultural and technical patrimony, which needs to be conserved in order to investigate and to spread out. Thus, traditional methods of bamboo felling depend on season have scientific foundations and technical justifications. In spite of the reasons and the emitted justification theory, cutting or extraction of bamboo are done mainly during the dry season and in morning hours as moisture content is low during these times due to low transpiration rate. Harvesting of bamboo may be done from October onwards till January as carbohydrates and moisture contents are least during these months. The extent of carbohydrates storage in culm tissues varied between the different heights levels of the culms and between seasons.

\section{Acknowledgement}

I do hereby acknowledge the authority of RFRI, Jorhat, Assam for permitting me to do Ph.D. in AdtU, Guwahati-26. I also would like to acknowledge the management of AdtU for providing me the all round facilities for carrying out my Ph.D. work. Especially I would like to acknowledge/ thank the authority of RFRI, Jorhat, Assam and Assam Agriculture
University, Jorhat for allowing me to use their laboratories for various research work related parameters.

\section{References}

[1] Beeson, C.F.C. 1961. The Ecology and Control of the Forest Insects of India and Neighbouring Countries. Government of India. First Reprint, 767p.

[2] Dutta, N. K. 2005. Fundamentals of Biochemistry, a practical approach. Kanishka Publishers, Distributors, New Delhi - 110002, 41-43p.

[3] Elena Bartkiene, 2012. Plant food analysis methods-a methodical book. Department of the Food Safety and Quality, Lithuanian university of Health Sciences Veterinary Academy, Kaunas.

[4] Gnanaharan, R. Mohanan, C and Chand Basha, S. 1993. Post-harvest technology of reed bamboo. BIC India Bulletin, 3(1): 1-6.

[5] Kumar, S., Shukla, K.S., Dev, I. and Dobriyal, P.B. 1994. Bamboo preservation technique: A review. Indian Council of Forestry Research \& Education, Dehra Dun \& International Network for Bamboo and Rattan, International Development Research Centre, Canada, 59 p.

[6] Liese, W. 1980. The preservation of bamboo. In: Bamboo Research in Asia. Proceedings of IDRC sponsored Workshop held in Singapore, May 1980: 165-178, IDRC, Singapore.

[7] Liese, W. 1985. Bamboo: Biology, Silvics, Properties, Utilization. Deutsche Gesellschsft fur Technische Zusammenarbelt (GTZ), Eschborn, Germany. 132pp.

[8] Mathew, G and Nair, K.S.S 1990. Storage Pests of Bamboo in Kerala. In Rao, I.V.R., Gnanarahan, R., Sastry, C.B. (Eds.) Proceedings of International bamboo 


\section{International Journal of Science and Research (IJSR) \\ ISSN (Online): 2319-7064}

Index Copernicus Value (2015): 78.96 | Impact Factor (2015): 6.391

workshop, Kerala Forest Research Institute (KFRI) Kerala and International Development research center (IDRC), Ottawa. 212-214p.

[9] Plank, H. K. 1950. Studies of factors influencing attack and control of the bamboo powder post beetle. Fed. Exp. Sta. Mayaguez, Puerto Rico. Bull. No. 48: 39p.

[10]Plank, H. K. 1951. Starch and other carbohydrates in relation to powder post beetle infestation in freshly harvested bamboo. Journ. Econo.Entom., 44(1): 73-75.

[11] Purushotham, A., Sudan, S. K and Vidya Sagar. 1953. Preservative treatment of green bamboos under low pneumatic pressures. The Indian Forester, 79(12): 652672.

[12] Sadasivam, S and Manickam, A. 1996. Biochemical methods. A biochemistry manual published by New Age International Pvt. Ltd. Publishers.

[13] Sulthoni, A. 1987. Traditional preservation of bamboo in Java, Indonesia. In: Rao, AX, Dhanarajan, G. and Sastry, C.B. Recent Research on Bamboos. Proceedings of the International Bamboo Workshop held at Hangzhou, People's Republic of China, October-6-14, 1985. Chinese Academy of Forestry, People's Republic of China \& International Development Research Centre, Canada, 349-357.

[14] Tomalang, F. N., Lopez, A. R., Semara, J. A., Casin, R. F and Espiloy, Z. B. 1980. Properties and utilization of Philippine erect bamboo. In International Seminar on Bamboo Research in Asia held in Singapore. Proceedings edited by G. Lessard and A. Chouinard. Singapore: International Development 44 Research Center and the International Union of Forestry Research Organization, Pp. 266-275. 